\title{
Pazarlama Amaçlı Sponsorluk Etkinlikleri ile Tüketici Temelli Marka Değeri Arasındaki İlişkinin İncelenmesi: Bir Türk Markası Ůzerine Tüketici Araştırması
}

\section{Investigation of the Relationship between Marketing Purpose Sponsorship Activities and Consumer Based Brand Equity: Consumer Research on a Turkish Brand}

\author{
Murat KOÇYİĞİT ${ }^{1 \oplus}$, Büşra KÜÇÜKCIVİL ${ }^{2 \oplus}$
}

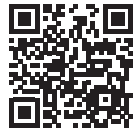

${ }^{1}$ Assoc. Prof., Necmettin Erbakan University, Faculty of Tourism, Department of Recreation Management, Konya, Turkey

${ }^{2}$ Res. Asst., Necmettin Erbakan University, Faculty of Social Sciences and Humanities, Department of Public Relations and Advertising, Konya, Turkey

\section{Sorumlu yazar/Corresponding author: Murat Koçyiğit, \\ Necmettin Erbakan Üniversitesi, Turizm Fakültesi, Rekreasyon Yönetimi Bölümü, Konya, Türkiye \\ E-posta/E-mail: mkocyigit@konya.edu.tr}

Geliş tarihi/Received: 21.05.2018 Kabul tarihi/Accepted: 26.11.2018

Atıf/Citation: Koçyiğit, M., \& Küçükcivil, B. (2018). Pazarlama amaçlı sponsorluk etkinlikleri ile tüketici temelli marka değeri arasındaki ilişkinin incelenmesi: Bir Türk markası üzerine tüketici araştırması. Connectist: Istanbul University Journal of Communication Sciences, 55, 113-141. https://doi.org/10.26650/CONNECTIST2018-0019 öz

Günümüz rekabet piyasasında stratejik bir halkla ilişkiler uygulaması olan sponsorluk faaliyetleri, markalar tarafından çeşitli iletişim amaçları için kullanılmaktadır. Bu amaçlar halkla ilişkiler, reklam ve pazarlama şeklinde kendini göstermektedir. Bu doğrultuda araştırmanın amacl; pazarlama amaçlı sponsorluk faaliyetleri ile tüketici temelli marka değeri arasında anlamlı bir ilişki olup olmadığını ve bu ilişkinin yönünü ve kuvvetini tespit etmektir. Araştırmada ölçek ifadeleri Arçelik markasının A Milli Takımlar sponsorluğu üzerinden kurgulanmış olup, kolayda örnekleme yöntemi vasıtasıyla, 412 katılımcı ile yüz yüze görüşme yöntemi doğrultusunda anket tekniği kullanılarak elde edilen veriler, pazarlama amaçlı sponsorluk faaliyetleri değişkeni ile tüketici temelli marka değeri bağlamında ölçüme tabi tutulmuştur. Bu doğrultuda, anket verileri ile değişkenler arasındaki ilişkilerin anlamı, kuvveti ve ortaya konulan hipotezler sınanmıştır. Bununla birlikte ilk olarak katılımcıların demografik değişkenleri frekans analizi yöntemi ile test edilmiştir. Daha sonra pazarlama amaçlı sponsorluk faaliyetleri ve marka değeri alt boyutları arasındaki ilişki ve etki düzeyini ölçmek amacı ile korelasyon ve basit doğrusal regresyon analizi gerçekleştirilmiştir. Araştırma bulgularına göre, pazarlama amaçlı sponsorluk faaliyetleri ile marka değeri alt boyutları ('marka sadakati', 'algılanan kalite', 'marka çağrışımı/bilinirliği', 'genel marka değeri') arasında anlamlı $(p=, 000)$ ve orta kuvvette bir ilişki olduğu tespit edilmiştir. Ayrıca yapılan basit doğrusal regresyon analizi sonucunda pazarlama amaçlı sponsorluk faaliyetlerinin, marka değeri alt boyutları üzerinde doğrudan ve anlamlı bir etkisi olduğu da tespit edilmiştir.

Anahtar Kelimeler: Sponsorluk, marka değeri, pazarlama, marka bilinirliği, marka sadakati 


\begin{abstract}
Sponsorship activities, which are a strategic public relations practice in today's competitive marketplace where capital wars are held, are used by brands for various communication aims. These aims are in the form of public relations, advertisement, and marketing. The aim of this research was to determine whether there is a significant relationship between sponsorship activities for marketing purposes and brand equity, and the direction and strength of this relationship. In this study, the scale expressions were fictionalized based on the sponsorship of National Teams of Arçelik brand. 412 people were surveyed using a questionnaire technique on the subject of brand equity. Accordingly, the meaning and strengths of the relations between data and variables, and the underlying hypotheses were tested. Firstly, the
\end{abstract}

demographic variables of the participants were explored. Correlation and simple linear regression analyses were then performed to measure the relationship and the level of effect between sponsorship activities for marketing purposes and brand equity sub-dimensions. According to the research findings, it was established that there is a significant $(p=, 000)$ and moderate impact relationship between sponsorship activities for marketing purposes and brand equity sub-dimensions ('brand loyalty', 'perceived quality', 'brand association/awareness', 'general brand equity'). Additionally, it was confirmed that as a result of simple linear regression analysis, sponsorship activities for marketing purposes have a direct and significant impact on brand equity sub-dimensions.

Keywords: Sponsorship, brand equity, marketing, brand awareness, brand loyalty

\section{EXTENDED ABSTRACT}

It is important that brands and corporations should maintain continuity and integrity in their communication with their target groups. This continuity and integrity is one of the most important elements that enable them to survive effectively in the market. Today, it has been observed that many brands and corporations benefit from a wide variety of sponsorship activities which enable them to communicate with their target groups. Sponsorship activities are investments that brands and corporations have made for a wide range of applications in their future. Sponsorship activities are divided into public relations, advertising and marketing based on the targeted objectives. However, it is impossible to say that there is a sharp distinction between them. Public relations, advertising and marketing activities complement each other, and have similar sponsorship objectives, just as a coherent flow is expected between brand and corporate communication elements. That is to say that if increasing the brand or corporate recognition or acquiring the goodwill of the community, which are among the public relations objectives of sponsorship, are not achieved by the brand or corporation as an outcome, promoting the use of products or increasing client loyalty can be challenging. In other words, advertising, public relations, and marketing objectives of sponsorship should be targeted together through continuous and integral communication of sponsorship. Such integrity is also essential for brand equity creation. The institutions or brands that 
desire to dominate the consumer's world should primarily create brand equity in their mind map. Brand equity is a concept with various sub-dimensions including brand awareness, brand association, brand loyalty, perceived quality and general brand equity. With the sponsorship applications aimed at marketing, such as introducing a new product, supporting the use of an existing product, positioning the product, supporting the dealers, creating a change in the marketing strategy, and supporting the international marketing strategy, awareness of, and association with a brand name can be developed in the target groups; the perceived quality can be raised, and client loyalty towards the brand can be achieved. In other words, the results of many scientific researches have shown that sponsorship practices are beneficial towards increasing the equity of a brand in general terms.

This study consists of three main sections. In the first part, the concepts of sponsorship for marketing and related subheadings are given. In the second part, the concept of brand equity and its sub-dimensions are mentioned. In the third and last section, the practical results of the research are described. Accordingly, information about the research method, data collection method and tools, and limitations, are given first. The findings of the socio-demographic characteristics of the participants, factor, correlation and regression analyzes of the variables are included in the final part.

This study was conducted to measure the impact of sponsorship activities for marketing purposes on consumer-based brand equity over the dates ranging from February 2018 to May 2018. The purpose of the study is to determine whether there is a meaningful relationship between the concept of brand equity at the consumer level and the sponsorship activities for marketing purposes, as well as to determine the direction and strength of the relationship between the two. The research was conducted with over 412 participants using a survey technique. In the two-part survey questionnaire, the scales developed by Speed and Thompson (2000) for measuring participants' perceptions on sponsorship for marketing purposes was used together with another scale by Yoo and Donthu (2001); Taşkın and Akat (2010) for measuring brand equity perception of consumers. The questionnaire was prepared as a Likert scale with 32 variables. Scale expressions of the research were prepared through the sponsorship of A National Teams of Arçelik brand. SPSS was used in the realization of the research analyses. According the factor analysis results, the sponsorship scale for marketing was perceived by the participants in one 
dimension while the brand equity scale was perceived by the participants in 4 subdimensions namely, brand awareness / brand association, perceived quality, brand loyalty and general brand equity.

According to the results of the correlation analysis, it was determined that there is a moderate strength and meaningful correlation between the sponsorship for marketing factor and the brand equity factor. According to these results, there is a significant positive relationship and strength of $\beta=500$ between the sponsorship for marketing factor, and the brand awareness / association factor; $\beta=462$ between sponsorship for marketing factor and the perceived quality factor; $\beta=480$ between sponsorship for marketing factor and the brand loyalty factor; and $\beta=508$ between the sponsorship for marketing factor and the general brand equity factor. When looking at the regression results, it was understood that the model is meaningful. According to the regression coefficient results, the correlation between brand awareness / brand association dependent variable and the sponsorship for marketing independent variable was $25 \%$. The perceived quality and the sponsorship for marketing purposes perception were found to $21.3 \%$ correlated. The rate of explaining the brand loyalty dependent variable of the sponsorship perception for marketing purposes variable is $23 \%$. Lastly, the link between the general brand equity and the sponsorship for marketing perception was $25.8 \%$. According to the results of both the previous study, which was obtained through literature review, and this study, which was carried out to determine the effect of sponsorship activities for marketing purposes on the consumer-based brand equity, sponsorship for marketing and brand equity significantly affect each other. 


\section{GíRiş}

Tarihsel süreç içerisinde sponsorluğun evrimine baktığımızda, öncelikle mesenlik/ hayırseverlik faaliyetleri ile başladığı kabul edilmektedir. Buna göre gerek batıda gerekse doğudaki devletler, krallıklar, imparatorluklar, soylular, zenginler ve toplumun önde gelen kesimleri bir takım toplumsal olaylara destek vermişlerdir. Bu desteği vermedeki amaç kimi zaman bir hedefe, çıkara dayalı iken, (itibar elde etme, olumsuz imajını olumluya çevirme, göz boyama vb.) kimi zaman da hiçbir yarar beklemeksizin karşı tarafa sadece destek verme mahiyetinde gerçekleştirilmiştir.

Sponsorluk uygulamaları zaman içerisinde mesenlik/hayırseverlik kavramlarından çok daha farkı bir boyuta taşınarak stratejik olarak algılanmaya başlanmıştır. Bu boyuta taşınmasındaki temel unsurlar sponsorluğun gelişme nedenleri olmakla birlikte pazardaki değişim doğrultusunda tüketicinin yaşam formu ve algısının değişmesi de diğer bir dikkat çekici nokta olmaktadır. Değişimin bir yansıması olarak sponsorluk uygulamalarının amacı halkla ilişkiler, reklam ve pazarlama şeklinde ayrıma tabi tutulmuştur. Bu bağlamda markalar ya da kurumlar toplumun iyi niyetini kazanmak, marka imajını değiştirmek, ürünleri desteklemek, radyo ve televizyonda reklamı yasak olan ürünleri duyurmak, marka değeri yaratmak, bir ürünü tanıtmak gibi pek çok sebepten ötürü sponsorluk yapmaktadırlar. Sponsorluğun amaçları her ne kadar halkla ilişkiler reklam ve pazarlama olarak ayrılsa da üç amaç arasında makas daralması olduğunu söylemek ve buradan hareketle planlanacak olan sponsorluk faaliyetlerinin amaçlarının birbirini beslemesi gerektiğini ifade etmek mümkündür.

Sponsorluk faaliyetlerinin kurum ya da markanın pazarlama amaçlarına hizmet etmesi ve bu doğrultuda pazarlama iletişimi elemanlarının bir unsuru olarak bu karmaya dâhil edilmesi 1970 'li ve 1980 'li yıllara tekabül etmektedir. Günümüze gelindiğinde ise kurumlar ve markalar tarafından sponsorluğa ayrılan bütçenin oldukça arttığı ve buna paralel olarak taraflar arasında imzalı iş anlaşması şeklinde aktifleştirilen bu uygulamadan beklentilerin de yükseldiği görülmektedir. Öyle ki günümüz pazarının yapısı ve tüketicinin dünyası oldukça karmaşık bir şablona sahiptir. Bu karmaşıklık içerisinde farklılık yaratma adına kullanılan sponsorluk faaliyetlerinin üzerine yüklenen misyon da doğru orantı ile artmaktadır. Etkisini ispat etmiş stratejik bir halkla ilişkiler uygulaması olan sponsorluk, rasyonel bir planlama dâhilinde uygulamaya geçirilirse faaliyetin geribildirimi oldukça pozitif olabilmektedir. Çünkü bugün güçlü sermayeler ile ayakta duran ve pek çoğunun 
pazar lideri olduğu markalara bakıldığında neredeyse tamamının muhakkak bir ya da birden fazla sponsorluk türüne yöneldiği ve bu şekilde marka iletişimini gerçekleştirdiği, markaya yönelik bir değer oluşturabildiği görülmektedir. Pazarlamaya yönelik gerçekleştirilen sponsorluk faaliyetleri, marka değeri alt boyutlarına hizmet edebilir, bu şekilde hedef kitle nezdinde marka bilinirliği yaratabilmekte, marka çağrışımına yardımcı olabilmekte, algılanan kaliteyi yükseltebilmekte ve bir marka sadakati yaratabilmektedir.

Bu çalışmada öncelikle, pazarlama amaçlı sponsorluk kavramına değinilmektedir. Bu bakımdan pazarlama amaçlı sponsorluk faaliyetlerine yönelik yerli ve yabancı literatürde bulunan ayrımlara, alt başlıklara yer verilmektedir. Sonrasında ise marka değeri ve alt boyutları kavramsal çerçevede ele alınmaktadır. Araştırmanın uygulamaya dönük kısmında yöntem, sınırlılıklar ve bulgulara değinilmektedir. Sonuç olarak, bu araştırmada pazarlama amaçlı sponsorluk faaliyetlerinin tüketici temelli marka değeri üzerinde bir etkisinin olup olmadığı, etkisi var ise ne yönde ve ne kuvvette olduğu seçilen örneklem grubu ve örnek marka üzerinden araştııılmıştır ve sonuçlar tablolar aracılığı ile şematize edilerek aktarılmaya çalışımıştır.

\section{Pazarlama Amaçlı Sponsorluk Kavramı}

Sponsorluk, bir kurum ile bir etkinlik ya da kurum dışı bir varlık arasında bağ kurarak tüketicilerin etkilenmesidir (Rifon, Choi, Trimble, \& Li, 2004, p. 29). Başka bir tanıma göre ise sponsorluk, belirlenmiş hedeflere ulaşmak için sponsor ile sponsorluğu yapılan arasında karşılıklı yarara dayanan bir anlaşmadır (Meerabeau et al., 1991, p. 39). Pazarlama tabanlı tanımına bakılacak olur ise sponsorluk, bir kurum ya da markanın çalışma alanları ile doğrudan ilişkisi olmayan bir etkinliğe destek vermesiyle, belirli hedef kitle üzerinde pozitif imaj yaratmaya çalışan önemli bir pazarlama iletişimi elemanıdır (Bennett, 1999, p. 291).

Sponsorluk, mütevazı bir başlangıçtan sofistike bir iletişim aracı haline ulaşmıştır. 1970'li yıllarda reklam ve kurumsal misafirperverlik için bir fırsattan çok az fazlası olan sponsorluk, günümüzde artık bir dizi pazarlama ve kurumsal iletişim amaçlarına ulaşmanın yoludur (Masterman, 2007, p. 11). Diğer bir deyişle, sponsorluk uygulamaları başlangıçta mesenlik/hayırseverlik faaliyetlerine dayanmaktadır ve bu dönemlerde günümüzdeki anlamı ile stratejik olarak kullanılmamıştır. Zaman içerisinde sponsorluğun aslında bir hayırseverlik ve mesenlik olmadığı anlaşılmış ve 
yukarıdaki tanımlardan da anlaşılacağı üzere tarafların yararına dayanan bir iş anlaşması olduğu kabul edilmiştir. Böylelikle kavram 1970'li yıllardan itibaren pazarlama iletişimi elemanı olarak kullanılmaya başlamıştır.

Sponsorluk kavramı, halkla ilişkiler, reklam, doğrudan pazarlama, satış promosyonu ve kişisel satış ile birlikte pazarlama iletişimi elemanları içerisinde yer almaktadır (Şekil 1) ve bu doğrultuda kurumun ya da markanın pazarlama amaçlarına hizmet etmektedir. Burada önemli olan noktalardan bir tanesi kurumun ya da markanın pazarlama ve iletişim anlamında amaçlamış olduğu başarıya ulaşabilmesi adına sponsorluk olayının ve olayın hedef kitlesinin uyumlu olması, örtüşmesidir. Bu durumu Ferrand ve arkadaşları Şekil 2'de betimlemektedirler.

Sponsorluğun zaman içerisinde evrilerek pazarlama iletişimi karmasının bir elemanı olması ve bu şekilde günümüzdeki konumuna erişmesini anlamak adına kavramın büyümesine/gelişmesine sebep olan bileşenlere değinmekte fayda vardır.

Sponsorluk faaliyetlerinin büyümesine etki eden faktörler pazardan pazara farklılık gösterse de temelde aşağıdaki sebeplere dayanmaktadır (Meenaghan, 1991, p. 5):

- Hükümetlerin tütün ve alkol reklamcılı̆̆ı hakkındaki politikaları,

- Reklam maliyetlerinin medyada yüksek olması,

- İnsanların boş vakitlerinden dolayı yeni fırsatların doğması,

- Sponsorluğun kendini kanıtlaması,

- Sponsorluk olayının medyada yer almasının artması,

- Geleneksel medyadaki verimsizlikler.

Bunlar sponsorluğun hem halkla ilişkiler, hem reklam, hem de pazarlama anlamında büyümesine etki eden faktörler olarak görülebilmektedir. Sponsorluğun özellikle bir pazarlama aracı olarak gelişmesine etki eden en önemli maddenin hükümetlerin tütün ve alkol endüstrisindeki kurumlar ve markalar için getirdiği kısıtlamaların sebep olduğunu söyleyebilmek mümkündür. Bu kısıtlamalar sayesinde geleneksel medyada reklam ve tanıtım engeline takılan alkol ve tütün sektöründeki kurum ve markalar buradan doğan iletişim boşluğunu doldurmak adına sponsorluk faaliyetlerine yönelmişlerdir. Bu durum da sponsorluk uygulamasının ciddi anlamda bir pazarlama aracı olarak görülmesine yol açmıştır. 
Kurumlar ve markalar için sponsorluk faaliyetlerinin çeşitli iletişim amaçları Jefkins (1992, p. 312). tarafından halkla ilişkiler, reklam ve pazarlama şeklinde ayrıma tabi tutulmaktadır. Pelsmacker ve arkadaşlarının yaptığı ayrım ise kurumsal iletişim amaçları ve pazarlama iletişim amaçları şeklinde kendini göstermektedir (Tablo 1).

Yapılan diğer çalışmalarda ise sponsorluğun pazarlama amaçları; yeni bir ürünü tanıtmak, ürün kullanımını desteklemek, ürünü konumlandırmak, bayileri desteklemek, pazarlama stratejisinde değişiklik oluşturmak, uluslararası pazarlama stratejisine destek olmak şeklinde ifade edilmektedir (Ferrand, Torrigiani, \& Povill, 2007, Peltekoğlu, 2016, Tengilimoğlu \& Öztürk, 2011).

Yeni Bir Ürünü Tanıtmak: Genel itibarı ile sponsorluğun en önemli nedenlerinden bir tanesi sponsorluk yolu ile kurumun, markanın ürününün adını büyük bir kitleye aktarabilme ve bunu tekrar tekrar yapabilme yeteneğidir (Henslowe, 1999, p. 63). Sponsorluk, sponsor markanın isminin yoğun bir şekilde tekrar edilmesini sağlar. İnsanlar aşina oldukları şeylere güvenmeye meyillidirler (Baines, Egan, \& Jefkins, 2004, p. 342). Sponsorlar bu faaliyetlerde ürünlerini sergileyerek tanıtırlar ve nasıl kullanılacağını da tüketicilere şu şekilde gösterebilirler; bir saat markası takım yarışmaları için zamanlama ekipmanı sağlayabilir, bir motor yağı markası motor yarışlarına sponsor olabilir, sponsorlar belirli ürün özelliklerine odaklanabilirler (Overton, 2007, p. 6). Bu şekilde hem sponsor markanın isminin hem de ürün adının aktarımı ile birlikte tanıtım yapmak mümkündür. Temellendirmenin esas olduğu tanıtım faaliyetlerinde öncelikle kurum, marka ve ürün isminin tekrar tekrar hedef kitleye sunulması ve bu bağlamda tanıtıma geçilmesi önemlidir.

Ürün Kullanımını Desteklemek: Ürün ya da hizmetin kullanımını desteklemek amacı ile gerçekleştirilen sponsorluk faaliyetlerinde, ürün-hizmet ve sponsorluk alanı arasında bağlantı sağlanmalıdır. Soğuk içecek üreticisinin televizyonda yayınlanan bir spor müsabakasının yayın sponsorluğunu yapması ya da patlamış mısır üreticisinin bir sinema filminin sponsorluğunu üstlenmesi bu bağlantıya örnek olarak verilebilir (Tengilimoğlu \& Öztürk, 2011, pp. 203-204).

Ürünü Konumlandırmak: Sponsorluk, bir ürünü pazarda konumlandırmak amacı ile gerçekleştirilebilmektedir. Coca Cola'nın gençlerin ilgi alanlarına yönelik gerçekleştirmiş olduğu sponsorluklar buna örnek olarak verilebilir (Jefkins, 1992, p. 312). Örneğin, motor yarışlarına sponsor olan bir markanın piyasa ve hedef kitle 
zihninde konumlanması/ imajı tehlike, heyecan ve risk üzerine olmakta iken opera sanatına sponsor olan bir markanın piyasa ve hedef kitle nezdinde konumlanması/ imajı elitist, seçkinci ve daha üst pazara hitap eden bir biçimdedir.

Bayileri Desteklemek: Başarılı bir sponsorluğun sonucunda markanın aktardığı olumlu imaj bayi satışlarını etkileyerek pazarlama amaçlarına hizmet etmektedir. Örneğin, bir yarışma sonucunda birincilik kazanan otomobil markasına olan talep artacak ve bu şekilde bayilerde performansını kanıtlanmış olan ürünleri teşhir etmeyi, satmayı tercih edeceklerdir (Peltekoğlu, 2016, p. 386).

Pazarlama Stratejisinde Değişiklik Oluşturmak: Sponsor, ürününü belirli bir pazarda tanımlamak isteyebilir. Örneğin, lavanta suyu üretimi yapan Yardley bu imajını yok etmek için motor yarışlarına sponsorluk yapmıştır (Jefkins, 1977, p. 292). Böylelikle eskiden olduğu gibi sadece kadınlara değil artık erkeklere de hitap ettiğini duyurma fırsatı elde etmiştir.

Uluslararası Pazarlama Stratejisine Destek Olmak: Sponsorluk, kültürel ve dilsel engelleri aşan bir uygulama olmasından ötürü uluslararası faaliyet gösteren kurumlar ve markalar için oldukça yararlı olabilmektedir. Faaliyetler, kurum ve marka yöneticilerinin müşteriler ile doğrudan ilişki kurmalarına imkân sunarken, müşterilere o kurumun ya da markanın ürünlerini ilk elden deneme fırsatı vermektedir (Amoako vd., 2012, p. 69). Bu anlamda sponsorluk, markanın isminin bilinmediği yabancı pazarlara girmesinin bir yolu olabilmektedir (Baines et al., 2004, p. 342). Diğer bir ifade ile kurum ya da markanın hitap ettiği ya da etmek istediği pazar küresel platformda ise uluslararası bir faaliyete sponsor olmak hem hedef kitleler üzerinde planlanmış amaçlara ulaşma hem de markanın global pazarlama politikasına hizmet etme avantajlarını bir arada taşımaktadır.

\section{Marka Değeri Kavramı ve Alt Boyutları}

Marka değerinin pek çok tanımı yapılmıştır, bunlardan en eski olanı David Ogilvy tarafından yapılmış olan tanımdır. Ona göre marka değeri, tüketicinin ürün hakkındaki düşüncesidir (Blackston, 1992, p. 79). Marka değeri, bir ürün ya da hizmetin bir firmaya ve/veya firmanın müşterisine sağladığı değeri artıran ya da azaltan, marka adı ve sembolü ile bağlantılı yükümlülükler ve varlıklar setidir (Aaker, 1996, pp. 7-8). 
Tüketici tabanlı marka değeri, markanın pazarlanmasında marka bilgisinin, tüketicinin vereceği tepkiyi farklılaştırıcı etkisi olarak tanımlanmaktadır (Keller, 1993, p. 8). Marka değeri kavramı, markaların hem kuruluşlar hem de hissedarlar açısından bir değer temsil ettiği anlayışının artmasından kaynaklanmaktadır. Bir değer olarak marka, firmanın mali refahına büyük ölçüde etki edebilir (Fill, Hughes, \& Francesco, 2013, p. 178).

Yüksek marka değeri bir şirkete çok fazla rekabet avantajı sağlayabilir (Kotler, Wong, V., Saunders, \& Armstrong, 2005, p. 556). Bu doğrultuda marka değerinin yüksek olması, yüksek marka bilinirliği ve marka sadakati nedeniyle bir firmanın pazarlama maliyetlerinin azalmasını sağlar, perakendeciler ve dağıtıcılar ile daha fazla pazarlık yapma imkânı sunar, algılanan kalite yüksek olduğundan dolayı firmanın daha fazla kar elde etmesini sağlar, fiyat rekabetine karşı daha fazla savunma fırsatı sunmasından ve yüksek güvenirliğinden dolayı pazar genişlemesinin daha kolay bir şekilde olmasına izin verir (Kotler, 2000, p. 189). Diğer bir bakış açısına göre (Temporal, 2015, pp. 88-89) marka değeri, esas olarak markanın vizyonundan kaynaklanmaktadır. Bunlar markanın neyi ifade ettiğini, inançlarını, insanlarla konuşması gereken sesi ve tavrını ve markanın tüketici ilişkileri açısından nasıl yönetileceğini tanımlayan somut ifadelerdir. Marka değeri, marka vizyonunu destekler ve bu vizyonun harekete nasıl geçirilebileceğini tanımlayan ifadelerin, sözcüklerin bir listesini sunar.

Marka değeri boyutları Aaker (1991), tarafından marka bilinirliği, marka çağrışımı, marka sadakati, algılanan kalite ve diğer marka varlıkları olmak üzere (Şekil 3.) 5 başlık altında toplanır iken yapılan diğer çalışmalarda, (Taşkın \& Akat, 2010; Yoo \& Donthu, 2001) marka değeri kavramı; marka bilinirliği/marka çağrışımı, marka sadakati, algılanan kalite, genel marka değeri olmak üzere 4 boyut olarak değerlendirilmektedir. Bu çalışmada da marka değeri; marka bilinirliği/marka çağrışımı, marka sadakati, algılanan kalite ve genel marka değeri başlıkları altında ele alınmıştır.

Marka Bilinirliği/Marka Çağrışımı: Potansiyel bir alıcının, bir markanın belirli bir ürün kategorisine dâhil olduğunu tanıması ve hatırlaması marka bilinirliğidir. Ürün sınıfı ve marka arasında bir bağlantının sağlanmasıdır (Aaker, 1991, p. 18). Marka bilinirliği, marka değerinin önemli, bazen de değeri düşük bir bileşenidir. Markaya dair bilinirlik, algıları ve tutumları etkileyebilmektedir (Şekil 4.). Şöyle ki, o bir fıstık ezmesinin tadını daha iyi hale getirebilir ve satıcılara güven aşılayabilir, marka seçiminin ve hatta marka sadakatinin itici bir gücü olabilir. Marka bilinirliği, markanın 
müşteri zihnindeki önemini yansıtmaktadır (Aaker, 1996, p. 114). Burada bahsedilen bilinirlik, markanın salt isminin ya da logosunun, veya ona dair herhangi bir unsurun bilinmesinden ibaret bir kavram değildir. Bilinirliğe dair tüketici zihninde hiyerarşik bir seviyeden bahsedilmektedir. Bu seviye Aaker (1996)'ın görüşü ile aşağıdaki şekilde ifade edilmektedir.

Marka Bilinirlik/Farkındalık Seviyeleri (Aaker, 1996, pp. 114-115):

- Markayı tanıma (x markasını hayatınızda hiç duydunuz mu?)

- Markayı hatırlama (otomobil markalarından hangisini hatırlıyorsunuz?)

- Illk hatırlanan marka (akla ilk gelen marka olmak)

- Marka baskınlığı (hatırlanan tek marka olmak)

- Marka bilgisi (markanın konumlanmasını bilme)

- Marka görüşü (marka hakkında sahip olunan fikir)

Çağrışımlar, ürünleri değerlendirme ve seçim yapmada önemli rol oynar. Ürün performansı hakkında bilgi almak için marka isimleri ve ürün özellikleri hakkında yapılan çağrışımlar ipuçları olarak kullanılır. Markalara dair bilgiler uzun süreli bellekte depolanır ve satın alma kararı alınırken ya da kategori ile ilgili değerlendirmelere dâhil olurken yeniden kullanılır. Marka çağrışımları, insanların marka ile ilgili bilgileri hafızada tutmaları ve bir markaya atfettikleri algıları ve anlamları içermeleri ile ilgilidir (Fill et al., 2013, p. 171). Tüketici ve marka arasında kurulacak olan ilişkide çağrışımlar önemlidir. Çünkü ikisi arasındaki etkileşimin gerçekleşmesinde çağrışımların yeri ve etkisi büyüktür. Güçlü markalara bakıldığında, tüketicilerinin zihninde marka çağrışımı için gerekli alt yapıları oluşturdukları ve bu sayede tüketicileri ile kuvvetli bir iletişimlerinin olduğu bunun da onların pazardaki yerini sağlamlaştırdığı görülmektedir.

Marka Sadakati: Marka sadakati, tüketicilerin herhangi bir ürün grubunda bulunan bir markanın ismini satın alma tercihidir (Erdil \& Uzun, 2010, p. 179). Sadakat bir kar akışına dönüşebildiği için marka sadakati, markalara değer katan önemli bir unsurdur. Örneğin sadık bir müşteri tabanının öngörülebilir bir satış ve kar akışı oluşturması beklenebilir. Ek olarak marka sadakatine odaklanmak, değeri yönetmenin etkili bir yoludur. Müşteri memnuniyeti ve tekrar satın alma durumları sıklıkla sağlıklı bir markanın göstergeleridir (Aaker, 1992, pp. 28-29). Tüketicilerin markaya olan sadakat seviyeleri kendi içerisinde farklılık göstermektedir. Bu farklılığı Pelsmacker ve 
arkadaşları tabandan tavana sadakat seviyesinin yükseldiği beş farklı parçadan oluşan marka sadakati piramidi ile ifade etmektedirler (Şekil 5.). Piramidin en alt seviyesindeki kitle, marka bağlılığı olmayan tüketicilerdir. En üst seviyesindeki kitle ise markaya kendini adamış tüketicilerdir.

Algılanan Kalite: Müşterinin markayı algılaması, ürün ya da hizmetin, markanın rakiplerine göre müşterinin zihninde amaç edindiği seviyeden daha üst bir seviyede olması algılanan kalitedir (Baş, 2015, p. 151). Müşterinin, farklı özellikleri ve şartları doğrultusunda beliren, psikolojik tatmin sağlayıcı özelliklere yönelik algılamalarını içeren algılanan kalite kavramı sübjektif bir kavramdır (Tosun, 2010, p. 132). Algılanan kalite kavramı tüketiciler ve markalar açısından öznel olarak algılanmakta ve değerlendirilmektedir.

Algılanan kalite farklı nedenlerden ötürü bir marka varlığı konumuna yükselen marka çağıışımıdır (Aaker, 1996, p. 17).

- Tüm marka çağrışımları arasında sadece algılanan kalitenin finansal performansı yönlendirdiği ortaya konulmuştur.

- Algılanan kalite genelde, bir işin başlıca belki de en önemli stratejik itici gücüdür.

- Algılanan kalite, bir markanın nasıl algılandığı konusundaki diğer olguları yönlendirir ve onlarla ilişkilendirir.

Genel Marka Değeri: Marka bilinirliği/marka çağrışımı, marka sadakati, algılanan kalite gibi marka değeri boyutlarını içine alan genel marka değeri, tutumsal, davranışsal ve tutum bazlı davranışsal yönlü, olumlu izlenim ve eğilimleri içine alan, tercih edilen ve beğenilen özelliklere sahip olma durumlarını içeren genel bir kapsama sahiptir.

\section{AMAÇ VE YÖNTEM}

Araştırmanın amacı; dayanıklı tüketim malları sektöründe faaliyet gösteren Arçelik markası tüketicileri üzerinden, pazarlama amaçlı sponsorluk faaliyetleri ile tüketici temelli marka değeri arasındaki ilişkileri 'doğrusal regresyon modeli' ile ortaya koymak ve bu doğrultuda tüketicilerin pazarlama amaçlı sponsorluk faaliyetlerine yönelik algılarının, tüketici temelli marka değeri üzerindeki etkilerini tespit etmeye yöneliktir. 
Araştırma kapsamı sonucunda toplanan veriler istatistik paket programı kullanılarak analiz edilmiştir. Bu bağlamda araştırma sonucunda elde edilen verileri değerlendirmek için kullanılacak testler şunlardır; tanımlayıcı istatistikler (frekans analizi), faktör analizi, korelâsyon analizi ve basit doğrusal regresyon analizidir. Bu analiz yöntemleri ile ölçülen ve pazarlama amaçlı sponsorluk algısı ile marka değeri arasındaki ilişkileri tespit etmek amacıyla belirlenen araştırma soruları ise şu şekildedir:

Araştırma Sorusu 1: Pazarlama Amaçlı Sponsorluk Algısı, Marka Sadakatini (MD) doğrudan ve anlamlı bir şekilde etkilemekte midir?

Araştırma Sorusu 2: Pazarlama Amaçlı Sponsorluk Algısı, Algılanan Kaliteyi (MD) doğrudan ve anlamlı bir şekilde etkilemekte midir?

Araştırma Sorusu 3: Pazarlama Amaçlı Sponsorluk Algısı, Marka Çağrışımı/Bilinirliğini (MD) doğrudan ve anlamlı bir şekilde etkilemekte midir?

Araştırma Sorusu 4: Pazarlama Amaçlı Sponsorluk Algısı, Genel Marka Değerini (MD) doğrudan ve anlamlı bir şekilde etkilemekte midir?

Araştırmada birincil verilerin elde edilmesi amacıyla en yaygın veri toplama yöntemlerinden biri olan anket (sormaca) tekniği kullanılmıştır. Araştırmada kullanılan anket formu 2 bölümden oluşmaktadır. Birinci bölümde; Speed \& Thompson (2000)'ın çalışmasından derlenerek kurgulanmış olan "pazarlama amaçlı sponsorluk algısı" ölçeği ile Yoo \& Donthu (2001); Taşkın \& Akat (2010)'ın çalışmalarından derlenerek uyarlanmış olan "tüketici temelli marka değeri" ölçeği kullanılmıştır. Anketin ikinci bölümü ise katılımcıların demografik özelliklerini tespit etmeye yönelik sorulardan oluşmaktadır.

Araştırma anket formu, Türkçe olarak hazırlanmıştır. Anket çalışmasında 2 bölümden oluşan toplam 32 gözlenen değişken bulunmaktadır. Başlangıçtaki 26 değişken araştırma modeli kapsamında kurgulanan Likert ölçeğine göre hazırlanmış ifadelerden oluşmaktadır. Gözlenen değişkenler oluşturulurken detaylı literatür çalışması yapılmış ve ankette bulunan sorular ile ilgili ulusal ve uluslararası literatürde yayınlanmış ve yukarıda da belirtilmiş olan çalışmalarda kullanılan ölçeklerden yararlanılmıştır. Ayrıca bu çalışmada ölçek ifadeleri Arçelik markası üzerinden kurgulanmıştır.

Araştırmanın evrenini, Konya il merkezinde yaşayan, dayanıklı tüketim malları sektöründe faaliyet gösteren Arçelik markası kullanıcıları (tüketicileri), oluşturmaktadır. Araştırma evreninin Arçelik markası kullanıcılarından oluşmasının 
sebebi, bu markanın A Milli Takımlar sponsorluğunu üstlenerek pazarlama amaçlı sponsorluk faaliyetini gerçekleştiriyor olmasındandır. Fakat araştırma kapsamında Arçelik markası kullanııılarının tamamına ulaşmak zaman kısıtı, maliyet ve örnekleme ulaşım zorluğundan dolayı, araştırma Konya ilinde olasılığa dayalı olmayan örnekleme türlerinden kolayda örnekleme yöntemi ile belirlenen tarihler arasında gerçekleştirilmiştir. Araştırma kapsamında 419 kişiye anket uygulanmış olup, 7 anket formu eksik ve hatalı veriler içermesi nedeniyle analizler 412 anket formu üzerinden gerçekleştirilmiştir.

Arçelik markası kullanııısı tüketicilerin, pazarlama amaçlı sponsorluk faaliyetleri ile ilgili algı ve düşüncelerinin, tüketici temelli marka değeri üzerindeki etkilerini tespit etmek amacıyla oluşturulan ölçeklerde yer alan ifadelerin tamamı 5'li Likert ölçeğine göre ölçeklendirilmiştir. Ölçek kapsamında hazırlanan ankette Likert ölçekli sorular 1-Kesinlikle Katılmıyorum; 2-Katılmıyorum; 3-Kararsızım; 4-Katılıyorum ve 5-Kesinlikle Katılıyorum değerlerini ifade etmektedir. Araştırmanın analizlerinin gerçekleştirilmesinde istatistiksel paket programı kullanılmıştır.

Araştırma verilerinin, zaman kısıtı ve örnekleme ulaşım zorluğundan dolayı, kolayda örnekleme yöntemi kullanılarak Konya'da ikamet eden dayanıklı tüketim malları sektöründe faaliyet gösteren Arçelik markası tüketicilerinden elde edilmiş olması, araştırmanın sınırlılıkları arasındadır. Araştırmanın bir diğer sınırlılığı ise sponsorluk faaliyetlerinin sadece pazarlama ayağı üzerinden çalışmanın yürütülmesi, halkla ilişkiler ve reklam üzerine merkezi bir odaklanmanın olmamasıdır. Diğer bir sınırlılık pazarlama amaçlı sponsorluk algısının marka değeri alt boyutları ile ilişkisine yönelik bir bakış açısı ile çalışmada daraltmaya gidilmesidir. Son olarak araştırma kurgusunun Arçelik markası üzerinden detaylandırılması ve araştırmanın Ocak 2018 Mart 2018 tarihleri arasında gerçekleştirilmiş olması da araştırmanın bir başka sınırlılığıdır.

Araştırma sonucunda elde edilmiş olan ve katılımcıların $(n=412)$ demografik özelliklerine (cinsiyet, yaş, eğitim durumu, medeni durum, aylık gelir durumu ve meslek) yönelik verileri betimleyen Tablo 2 . incelendiğinde, katılımcıların \%51,7'si erkek \%48,3'ü kadındır. Katılımcıların yaş aralıklarına bakıldığında, 18-24 yaş aralığında olanların \%29,6, 25-31 yaş aralığında olanların \%25,7, 32-38 yaş aralığında olanların \%18,8, 39-45 yaş aralığında olanların $\% 13,8$ ve son olarak 46 yaş ve üzeri aralıkta olanların ise \%12,1 oranlarına sahip olduğu anlaşılmaktadır. Katılımcıların 
diğer bir demografik özelliği olan eğitim durumlarına bakıldığında ise, \%37,6'sı lise, $\% 26$ 'sı lisans, \%12,9'u önlisans, \%12,1'i ortaokul, \%7,5'i ilkokul, \%3,9'u lisansüstüdür. Araştırmaya dâhil olan bireylerin medeni durumlarına bakıldığında \%64,6'sının bekâr olduğu, \%35,4'ünün ise evli olduğu tespit edilmiştir. Katılımcıların aylık gelir durumları incelendiğinde \%29,1'inin aylık gelir miktarının 2501 TL ve üzeri, \%23,8'inin 20012500 TL, \%21,4'ünün 1000 TL'den az, \%15,8'inin 1501-2000 TL, \%10'unun ise 10011500 TL aralıklarında olduğu görülmektedir. Katılımcıların mesleklerine dair bulgular içeren Tablo 2'e bakıldığında \%34'ü öğrenci, \%29,9'u memur, \%11,9'u iş̧̧i, \%10,7'si özel sektör çalışanı, \%8,3'ü diğer alanlarda ve son olarak \%5,3'ü serbest meslek sahibidir.

\section{BULGULAR}

Araştırmaya dair bulguların yer aldığı bu başlık altında pazarlama amaçlı sponsorluk ölçeğinin faktör analizine, marka değeri ölçeğinin faktör analizine, pazarlama amaçlı sponsorluk algısı ile marka değeri arasındaki korelasyon ve regresyon analizlerine yer verilmektedir. Bununla birlikte katılımcıların sosyodemografik özellikleri araştırmanın yöntem bölümünde ifade edilmiştir.

\section{Pazarlama Amaçlı Sponsorluk Ölçeği Faktör Analizi Sonuçları}

Pazarlama amaçı sponsorluk ölçeğinin katılımcılar tarafından kaç alt boyutta algılandığının tespit edilmesi için gerçekleştirilen faktör analizi sonuçlarına yer verilmektedir. Verilerin faktör analizine uygun olup olmadığı KMO ve Barlett testleri ile belirlenmiştir. Pazarlama amaçlı sponsorluk ölçeği için gerçekleştirilen faktör analizi sonucuna göre Kaiser-Meyer-Olkin $(\mathrm{KMO}=917)$ ile soru grubunun tamamının faktör analizine uygunluğu ölçülmüştür. Bu ölçüm sırasında Measures of Sampling Adequacy-Örnekleme Yeterliliğinin Ölçümü (MSA) yöntemi kullanılarak değişkenlerin anti-image korelasyon matrisine bakılmıştır ve anti-image korelasyon matrisindeki MSA değerleri incelendiğinde tüm değişkenlerin değerinin 0,50'nin üzerinde olduğu tespit edilmiştir. Faktör analizi sonuçlarına göre, katılımcıların pazarlama amaçlı sponsorluk ölçeğini tek bir boyut altında algıladıkları tespit edilmiştir. Tek bir boyut altında algılanan bu faktörün ölçeği açıklayabilme yüzdesi 62,106'dır. Cronbach Alpha katsayısı ise, 923 'dür. Bu değer \%60'ın üzerinde olduğu için pazarlama amaçlı sponsorluk ölçeği faktörünün istatistiksel olarak güvenilir olduğu sonucu elde edilmiştir (Tablo 3). 


\section{Marka Değeri Ölçeği Faktör Analizi Sonuçları}

Katılımcıların marka değeri ölçeğini kaç boyut altında algıladıklarını tespit etmek amacıyla gerçekleştirilen faktör analizi sonuçlarına yer verilmektedir. Verilerin faktör analizine uygunluğu için KMO ve Barlett testleri yapılmıştır. Marka değeri ölçeği faktör analizi sonucunda Kaiser-Meyer-Olkin $(K M O=, 909)$ ile bütün soru grubunun genel faktör analizine uygunluğu ölçülmüştür. Bu ölçüm işlemi gerçekleştirilirken Measures of Sampling Adequacy-Örnekleme Yeterliliğinin Ölçümü (MSA) yöntemi kullanılarak değişkenlerin anti-image korelasyon matrisi gözden geçirilmiştir. Anti-image korelasyon matrisindeki MSA değerleri incelendiğinde tüm değişkenlerin 0,50 değerinin üzerinde olduğu tespit edilmiştir. Faktör analizi sonucunda gözlenen değişkenlerden bir tanesini oluşturan soru 22 'nin birden fazla faktör altında yakın değerler aldığı tespit edilmiştir. Herhangi bir sorunun farklı faktör sütunlarında yakın değerler alması söz konusu ise sorunun analiz dışı bırakılması gerekmektedir (Durmuş, Yurtkoru, \& Çinko, 2013, p. 85). Bu sebeple soru 22 analiz dışı bırakılarak tekrar faktör analizi yapılmıştır. Bu aşamada ortaya çıkan faktör tablosunda herhangi bir probleme rastlanmadığı için analize bu hali ile devam edilmiştir. Faktör analizi sonuçlarına göre katılımcılar, marka değeri ölçeğini 4 alt boyutta algılamışlardır. Bunlar; Marka Sadakati, Algılanan Kalite, Marka Bilinirliği/Çağrışımı, Genel Marka Değeri şeklindedir. Faktör analizi sonuçlarına göre, marka sadakati faktörü \%19,385, algılanan kalite faktörü $\% 16,793$, marka bilinirliği/çağrışımı \%16,656, genel marka değeri $\% 16,032$ oranında katkı sağlayarak bu şekilde alt faktörler ölçeğin toplamda \%68,866'sını açıklamışlardır. Her bir faktörün kendi içerisindeki güvenirliği ölçülmüştür ve bu ölçüm değerleri Cronbach Alpha katsayısı olarak tabloya yerleştirilmiştir. Marka değeri ölçeğinin tüm alt boyutlarında Cronbach Alpha değerleri \%60'ın üstünde yer aldığı için faktörlerin istatistik olarak güvenilir olduğu sonucu elde edilmiştir (Tablo 4).

\section{Pazarlama Amaçlı Sponsorluk Algısı ve Marka Değeri İlişkisi}

Çalışmanın bu bölümünde pazarlama amaçlı sponsorluk algısı ve marka değeri alt boyutları arasındaki ilişkileri tespit etmek amacıyla ilk olarak korelasyon analizi gerçekleştirilmiştir. Sonrasında ise, pazarlama amaçlı sponsorluk faktörünün, marka değeri alt boyutları üzerindeki rolünü/etkisini belirlemek amacı ile basit doğrusal regresyon analizi gerçekleştirilmiştir. 
Tablo 5. incelendiğinde pazarlama amaçlı sponsorluk ölçeği faktörü bağımsız değişkeni ile marka değeri ölçeği alt boyutları bağımlı değişkenleri (marka sadakati, algılanan kalite, marka bilinirliği/çağrışımı, genel marka değeri) arasında 0,01 düzeyinde anlamlı ilişkiler olduğu anlaşılmıştır. Buna göre, pazarlama amaçlı sponsorluk faktörü ile marka değeri alt boyutları faktörleri arasında orta kuvvette anlamlı ilişkiler olduğu tespit edilmiştir. Pazarlama amaçlı sponsorluk faktörü ile marka sadakati arasında $r=480$, pazarlama amaçlı sponsorluk faktörü ile algılanan kalite arasında $r=462$, pazarlama amaçlı sponsorluk faktörü ile marka çağrışımı/ bilinirliği arasında $r=500$ ve son olarak yine pazarlama amaçlı sponsorluk faktörü ile genel marka değeri arasında $r=508$ kuvvetinde anlamlı pozitif bir ilişki olduğu (Tablo 5) tespit edilmiştir.

Pazarlama amaçlı sponsorluk algısı ve marka değeri alt boyutları regresyon katsayılarını betimleyen Tablo 6. İncelendiğinde F istatistik değerleri ve p değerleri doğrultusunda modelin anlamlı olduğu sonucuna ulaşılmaktadır. Pazarlama amaçlı sponsorluk algısı bağımsız değişkeninin, marka sadakati bağımlı değişkenini açıklayabilme oranı \%23'tür. Pazarlama amaçlı sponsorluk algısı değişkeninin bağımlı değişken olan algılanan kalite değişkenini açıklayabilme oranı \%21,3'dür. Bağımsız değişken olan pazarlama amaçlı sponsorluk algısının, bağımlı değişken olan marka çağrışımı/bilinirliğini açıklayabilme oranı \%25'tir ve son olarak yine pazarlama amaçlı sponsorluk algısı değişkeninin genel marka değeri değişkenini açıklayabilme oranı $\% 25,8^{\prime}$ dir.

Regresyon analizi sonuçlarına göre, bağımsız değişkenin marka değeri bağımlı değişkeni üzerinden anlamlı ,508 kuvvetinde bir etkisi olduğu tespit edilmiştir. Sonra sırası ile bağımlı değişkenler üzerinde (marka çağrışımı/bilinirliği, marka sadakati, algılanan kalite) pazarlama amaçlı sponsorluk değişkeninin anlamlı bir etkiye sahip olduğu görülmektedir.

\section{TARTIŞMA VE SONUÇ}

Markalar ve kurumlar adına oldukça etkin bir rekabet ortamının olduğu günümüz dünyasında, pazarlama amaçlı iletişim kurmak farkındalık yaratma adına önemlidir. Tüketicilerle kurulmuş olan bu iletişim, markanın pazardaki konumunu koruması ya da daha iyi bir pozisyona taşıması açısından belirleyici bir faktördür. Bir markanın mevcut konumunu koruması ya da daha iyi bir konuma ulaşarak 
rakiplerinden sıyrılması onun hedef kitlesi ile kurmuş olduğu bağlantıya önem vermesine dayanmaktadır. Hedef tüketicilerin bilişsel dünyasında istenilen düşünceleri yaratarak onun algılarını yönetmek ve sadık bir müşteri olmasını sağlamak için bir marka değeri oluşturulması gerekmektedir. Bu değeri oluştururken kullanılan pek çok unsurdan bir tanesi olan sponsorluk uygulamaları, belirlenmiş hedef kitlede bir marka çağrışımı, bilinirliği, sadakati ve kalite algısı yaratmada sistematik bir şekilde kullanılmaktadır. Sponsorluk uygulamaları halkla ilişkiler, reklam ve pazarlama amaçlarından hangisi için gerçekleştirilecek olursa olsun kuruma ya da markaya yönelik dönütleri uzun vadede olacağından ötürü zaman ve sabır gerektiren bir planlama istemektedir. Bunun yanında kurumsal ve marka iletişiminin diğer unsurları ile koordine biçimde bir hareketlenmeye de ihtiyaç duymaktadır. Bu şekilde kurumsal ve marka iletişiminde bir bütünlük sağlanır. Araştırma ile benzer daha önce yapılmış çalışmalara bakıldığında şu sonuçların elde edildiği görülmektedir.

Karadeniz (2009) tarafından yapılmış çalışmanın sonucu, iyi planlanmış ve organize olmuş sponsorluk faaliyetleri tüketiciler üzerinde oldukça fazla bir etki yaratacağından dolayı hem kurum hem de ürün üzerinde yüksek bir farkındalığa sebep olabilecektir. Dikkat edilmesi gereken nokta hedef kitlenin iyi seçilerek planlamanın buna yönelik yapılmasıdır.

Dumanlı (2011) tarafından gerçekleştirilmiş çalışmanın sonuçlarına göre, stratejik biçimde belirlenip gerçekleştirilen sponsorluk etkinlikleri, bir kurumun marka değerine ve marka değeri alt boyutlarına olumlu katkı sağlamaktadır.

Erciş (2012) tarafından yılında gerçekleştirilmiş olan çalışma doğrultusunda ulaşılan bulgulara göre, Türk Hava Yollarının elde etmiş olduğu tanınmışlık ve başarısında sponsorluk uygulamalarındaki etkinliğin yerinin büyük olduğu sonucuna varılmıştır.

Kürkçü (2015), tarafından gerçekleştirilen çalışmadan elde edilen sonuçlara göre, araştırmaya söz konusu olan Türk Telekom markasının sponsorluk faaliyetinden hedef kitlenin haberdar olduğu ve sponsorluk faaliyetleri sayesinde bir ölçüde markaya karşı sadakatlerinin arttığı tespit edilmiştir. Türk Telekom markası hâlihazırda farkındalığı yüksek bir markadır. Bu doğrultuda markanın sponsorluk faaliyetlerinin farkındalığı da yüksek olmaktadır. 
Ertekin (2016) tarafından gerçekleştirilen araştırma sonuçlarına göre, maraton katılımcılarının sponsorluk ve marka değeri etkileşimini oluşturan unsurlar, marka sadakati, marka çağrışımı ve algılanan kalite olarak sıralanmıştır. Araştırmaya dâhil olanların büyük bir çoğunluğunun araştırma markası olan Vodafone markasını tanıdığı ve maratondan televizyon vasıtası ile haberdar olduğu sonucuna ulaşılmıştır. $\mathrm{Bu}$ araştırmanın ampirik sonuçlarına göre ise, pazarlama amaçlı sponsorluk faaliyetlerinin oluşturduğu algı ile marka değeri alt boyutları olan; marka sadakati, algılanan kalite, marka çağrışımı/bilinirliği ve genel marka değeri arasında orta kuvvette, anlamlı, pozitif bir ilişki olduğu tespit edilmiştir. Başka bir deyişle pazarlama amaçlı sponsorluk faktörü ile marka değeri faktörü birbirini olumlu ya da olumsuz yönde etkileyebilen iki unsurdur. Literatür taraması doğrultusunda ulaşılan yukardaki çalışmaların bulguları ile bu çalışmanın bulguları paralellik göstermektedir. Bir diğer deyişle pazarlama amaçlı sponsorluk faaliyetlerinin marka değeri üzerinde pozitif bir etkisi olduğu, hedef kitle nezdinde markaya dair bir bilinirlik oluşturduğu, çağrışımlar ile markayı anımsattığı, markanın algılanan kalitesini yükselttiği ve marka sadakatini artırdığı bu çalışmanın önemli bulguları arasında yer almaktadır. Ayrıca bu konuda yapılmış olan pek çok akademik çalışmada da benzer bulgulara ulaşıldığı tespit edilmiştir.

\section{KAYNAKLAR}

Aaker, D. (1991). Managing brand equity capitalizing on the value of a brand name. New York, NY: Simon \& Schuster.

Aaker, D. (1992). The value of brand equity. Journal of Business Strategy, 13(4), 27-32.

Aaker, D. (1996). Measuring brand equity across products and markets. California Management Review, 38(3), $102-120$.

Aaker, D. (1996). Building strong brands. New York, NY: Simon \& Schuster.

Amoako, G. K., Dartey-Baah, K., Dzogbenuku, R. K., \& Junior, S. K. (2012). The effect of sponsorship on marketing communication performance: A case study of Airtel Ghana. African Journal of Marketing Management, 4(2), $65-79$.

Baines, P., Egan, J., \& Jefkins, F. (2004). Public relations contemporary issues and techniques. Oxford, UK: Elsevier. Baş, M. (2015). Marka yönetimi. Ankara, Turkey: Detay Yayıncılık.

Bennett, R. (1999). Sport sponsorship, spectator recall and false consensus. European Journal of Marketing, 33(34), 291-313.

Blackston, M. (1992). Observations: Building brand equity by managing the brand's relationships. Journal of Advertising Research, 32(3), 79-83. 
Dumanlı, D. (2011). Sponsorluk etkinliklerinin marka değeri üzerine etkisi ve uygulama örneği. (Yüksek Lisans Tezi). Marmara Üniversitesi Sosyal Bilimler Enstitüsü, İstanbul, Turkey.

Durmuş, B., Yurtkoru, E. S., \& Çinko, M. (2013). Sosyal bilimlerde SPSS'le veri analizi. İstanbul, Turkey: Beta Yayıncılık. Erciş, M. S. (2012). Pazarlama iletişimi kapsamında sponsorluk faaliyetlerinin önemi ve bir sponsorluk uygulaması: Türk Hava Yolları. Marmara Iletişim Dergisi, 19, 112-124.

Erdil, T. S., \& Uzun, Y. (2010). Marka olmak. İstanbul, Turkey: Beta Basım Yayım.

Ertekin, A. B. (2016). Uluslararası spor organizasyonlarindaki sponsorluğun kurumların marka değeri üzerine yarattığı etkinin incelenmesi. (Doktora Tezi). Marmara Üniversitesi Sağlık Bilimleri Enstitüsü, İstanbul, Turkey.

Ferrand, A., Torrigiani L., \& Povill, A. C. (2007). Routledge handbook of sports sponsorship successful strategies. London, UK: Routledge.

Fill, C., Hughes, G., \& Francesco, S. D. (2013). Advertising strategy, creativity and media. UK: Pearson Education Ltd. Henslowe, P. (1999). Public relations a practical guide to the basics. London, UK: Kogan Page Ltd.

Jefkins, F. (1977). Advertising today. London, UK: International Textbook Company Ltd.

Jefkins, F. (1992). Advertising. London, UK: Made Simple Books.

Karadeniz, M. (2009). Pazarlama iletişimi kapsamında sponsorluk faaliyetlerinin önemi. Journal of Naval Science and Engineering, 5(1), 62-75.

Keller, K. L. (1993). Conceptualizing, measuring and managing consumer-based brand equity. Journal of Marketing, 57(1), 1-22.

Kotler, P. (2000). Marketing management. Millenium edition. New Jersey, US: Pearson Custom Publishing.

Kotler, P., Wong, V., Saunders, J., \& Armstrong, G. (2005). Principles of marketing. England: Pearson Education Limited.

Kürkçü, D. D. (2015). Sponsorluğun marka değeri üzerine etkisi. Yıldız Journal of Art and Design, 2(1), 1-18.

Masterman, G. (2007). Sponsorship for a return on investment. Oxford, UK: Elsevier.

Meenaghan, T. (1991). Sponsorship-legitimising the medium. European Journal of Marketing, 25(11), 5-10.

Meerabeau, E., Gillett, R., Kennedy, M., Adeoba, J., Byass M., \& Tabi, K. (1991). Sponsorship and the drinks industry in the 1990s. European Journal of Marketing, 25(11), 39-56.

Overton, R. (2007). Sponsorships findings and selling marketing partnerships. Australia: Martin Books Pty.

Pelsmacker, P. D., Geuens, M., \& Bergh, J. V. (2010). Marketing communications: A European perspective. UK: Pearson Education.

Peltekoğlu, F. B. (2016). Halkla ilişkiler nedir? İstanbul, Turkey: Beta Basım Yayım.

Rifon, N. J., Choi, S, M., Trimble, C. S., \& Li, H. (2004). Congruence effects in sponsorship the mediating role of sponsor credibility and consumer attributions of sponsor motive. Journal of Advertising, 33(1), $29-42$.

Speed, R., \& Thompson, P. (2000). Determinants of sport sponsorship response. Journal of the Academy of Marketing Science, 28(2), 226-238.

Taşkın, Ç., \& Akat, Ö. (2010). Tüketici temelli marka değerinin yapısal eşitlik modelleme ile ölçümü ve dayanikli tüketim mallari sektöründe bir araştırma. İşletme ve Ekonomi Araştırmaları Dergisi, 1(2), 1-16. 
Temporal, P. (2015). Branding for the public sector creating, building and managing brands people will value. Chichester, UK: John Wiley and Sons.

Tengilimoğlu, D., \& Öztürk, Y. (2011). İşletmelerde halkla ilişkiler. Ankara, Turkey: Seçkin Yayıncılık.

Tosun, N. B. (2010). Iletişim temelli marka yönetimi. İstanbul, Turkey: Beta Basım Yayım Dağıtım A.Ş.

Yoo, B., \& Donthu, N. (2001). Developing and validating a multidimensional consumer-based brand equity scale. Journal of Business Research, 52, 1-14. 


\section{TABLOLAR VE ŞEKILLER}

\section{Tablo 1: Sponsorluğun Amaçları}

\begin{tabular}{|c|c|c|}
\hline \multirow{4}{*}{$\begin{array}{l}\text { Kurumsal } \\
\text { İletişim } \\
\text { Amaçları }\end{array}$} & Genel Kamu & $\begin{array}{l}\text { Kurumun genel kamu bilincini yükseltmek } \\
\text { Kurumsal imajı artırmak } \\
\text { Kurumun kamu algısını değiştirmek } \\
\text { Yerel halka dâhil olmak }\end{array}$ \\
\hline & $\begin{array}{l}\text { Kanal Üyeleri ve Ticari } \\
\text { îlişkiler }\end{array}$ & $\begin{array}{l}\text { Ticari ilişkiler kurmak, } \\
\text { Kurumsal misafirperverlik } \\
\text { Ticari iyi niyet göstermek }\end{array}$ \\
\hline & Çalışanlar & $\begin{array}{l}\text { Çalışan ilişkilerini ve motivasyonlarını geliştirmek } \\
\text { Personel alımına yardım etme } \\
\text { Satış ekibi için arama sürecini kolaylaştırmak }\end{array}$ \\
\hline & $\begin{array}{c}\text { Kanaat Oluşturucular } \\
\text { ve } \\
\text { Karar Vericiler }\end{array}$ & $\begin{array}{l}\text { Medyanın ilgisini artırmak } \\
\text { Olumsuz tanıtıma karşı koymak } \\
\text { İyi niyet inşa etmek } \\
\text { Politika sahiplerine ve hissedarlara güvence vermek } \\
\text { Üst düzey yöneticilerin kişisel amacı }\end{array}$ \\
\hline \multirow{3}{*}{$\begin{array}{l}\text { Pazarlama } \\
\text { İletişimi } \\
\text { Amaçları }\end{array}$} & Farkındalık Oluşturma & $\begin{array}{l}\text { Mevcut müşterilerin farkındalığını artırmak } \\
\text { Potansiyel müşterilerin farkındalığını artırmak } \\
\text { Pazar liderliğini onaylamak } \\
\text { Yeni ürün farkındalığını artırmak }\end{array}$ \\
\hline & Marka İmajı & $\begin{array}{l}\text { Marka algısını değiştirmek } \\
\text { Markayı belirli bir pazar segmenti ile tanımlamak }\end{array}$ \\
\hline & Satış/Pazar Payı & $\begin{array}{l}\text { Yeni ürünün denemesini başlatmak } \\
\text { Satış/Pazar payını artırmak }\end{array}$ \\
\hline
\end{tabular}

Kaynak: Pelsmacker et al., 2010, p. 377. 
Tablo 2: Katılımcıların Sosyo-Demografik Özellikleri ( $n=412)$

\begin{tabular}{|c|c|c|c|c|c|c|c|}
\hline $\begin{array}{l}\text { Demografik } \\
\text { Değişkenler }\end{array}$ & Değer & Frekans & Yüzde & $\begin{array}{l}\text { Demografik } \\
\text { Değişkenler }\end{array}$ & Değer & Frekans & Yüzde \\
\hline \multirow{3}{*}{ Cinsiyet } & Erkek & 213 & 51,7 & \multirow{3}{*}{$\begin{array}{l}\text { Medeni } \\
\text { Durum }\end{array}$} & Bekâr & 266 & 64,6 \\
\hline & Kadın & 199 & 48,3 & & Evli & 146 & 35,4 \\
\hline & Toplam & 412 & 100,0 & & Toplam & 412 & 100,0 \\
\hline \multirow{6}{*}{ Yaş } & $18-24$ & 122 & 29,6 & \multirow{6}{*}{$\begin{array}{c}\text { Aylık } \\
\text { Gelir Durumu }\end{array}$} & $\begin{array}{c}1000 \text { TL'den } \\
\text { Az }\end{array}$ & 88 & 21,4 \\
\hline & $25-31$ & 106 & 25,7 & & $1001-1500$ & 41 & 10,0 \\
\hline & $32-38$ & 77 & 18,7 & & $1501-2000$ & 65 & 15,8 \\
\hline & $39-45$ & 57 & 13,8 & & $2001-2500$ & 98 & 23,8 \\
\hline & $46+$ & 50 & 12,1 & & 2501 ve üzeri & 120 & 29,1 \\
\hline & Toplam & 412 & 100,0 & & Toplam & 412 & 100,0 \\
\hline \multirow{7}{*}{$\begin{array}{l}\text { Eğitim } \\
\text { Durumu }\end{array}$} & İlkokul & 31 & 7,5 & \multirow{7}{*}{ Meslek } & $\begin{array}{l}\text { Serbest } \\
\text { Meslek }\end{array}$ & 22 & 5,3 \\
\hline & Ortaokul & 50 & 12,1 & & Memur & 123 & 29,9 \\
\hline & Lise & 155 & 37,6 & & İşçi & 49 & 11,9 \\
\hline & Önlisans & 53 & 12,9 & & $\begin{array}{c}\text { Özel Sektör } \\
\text { Çalışanı }\end{array}$ & 44 & 10,7 \\
\hline & Lisans & 107 & 26,0 & & Öğrenci & 140 & 34,0 \\
\hline & Lisansüstü & 16 & 3,9 & & Diğer & 34 & 8,3 \\
\hline & Toplam & 412 & 100,0 & & Toplam & 412 & 100,0 \\
\hline
\end{tabular}


Tablo 3: Pazarlama Amaçlı Sponsorluk Ölçeği Faktör Yapısı

\begin{tabular}{|c|c|c|c|}
\hline \multirow[t]{2}{*}{ Faktör } & \multirow[t]{2}{*}{ Değişkenler } & $\begin{array}{l}\text { Faktör } \\
\text { Yapısı }\end{array}$ & \multirow{2}{*}{$\begin{array}{l}\text { Cronbach } \\
\text { Alpha }\end{array}$} \\
\hline & & 1 & \\
\hline \multirow{9}{*}{ 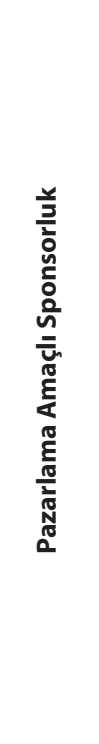 } & $\begin{array}{l}\text { S5. Bu sponsorluk sponsorun reklamlarına daha çok dikkat } \\
\text { etmemi sağladı. }\end{array}$ &, 822 & \multirow{9}{*}{,923 } \\
\hline & $\begin{array}{l}\text { S8. Bu sponsorluk sponsor markanın ürünlerini tekrar } \\
\text { satın alma olasılığımı artırdı. }\end{array}$ & 820 & \\
\hline & $\begin{array}{l}\text { S3. Bu sponsorluk sponsor markaya karşı daha fazla } \\
\text { sempati duymamı sağladı. }\end{array}$ & 818 & \\
\hline & $\begin{array}{l}\text { S2. Bu sponsorluk sponsor markaya yönelik farkındalığımı } \\
\text { artırdı. }\end{array}$ &, 816 & \\
\hline & $\begin{array}{l}\text { S6. Bu sponsorluk sponsor markayı daha çok hatırlamamı } \\
\text { sağladı. }\end{array}$ & 802 & \\
\hline & $\begin{array}{l}\text { S4. Bu sponsorluk sponsorun adını başka zamanlarda da } \\
\text { fark etmemi sağladı. }\end{array}$ & ,792 & \\
\hline & $\begin{array}{l}\text { S7. Bu sponsorluk sponsor markanın ürününü daha çok } \\
\text { kullanmamı sağladı. }\end{array}$ & ,789 & \\
\hline & $\begin{array}{l}\text { S1. Bu sponsorluk sponsor markaya yönelik düşüncelerimi } \\
\text { olumlu yönde etkiledi. }\end{array}$ & ,757 & \\
\hline & $\begin{array}{l}\text { S9. Bu sponsorluğun bir sonucu olarak sponsor markaya } \\
\text { yönelik bağlıı̆ım arttı. }\end{array}$ &, 664 & \\
\hline & ÖZDEĞER & 5,590 & \\
\hline & AÇIKLANAN VARYANS & 62,106 & \\
\hline & TOPLAM AÇIKLANAN VARYANS & 62,106 & \\
\hline & KMO & ,917 & \\
\hline & BARLETT & $\begin{array}{c}2440,957 \\
\text { (sd. } 36 ; p=0,000)\end{array}$ & \\
\hline
\end{tabular}


Tablo 4: Marka Değeri Ölçeği Faktör Yapısı

\begin{tabular}{|c|c|c|c|c|c|c|}
\hline \multirow{2}{*}{ Faktör } & \multirow{2}{*}{ Değişkenler } & \multicolumn{4}{|c|}{ Faktör Yapısı } & \multirow{2}{*}{$\begin{array}{l}\text { Cronbach } \\
\text { Alpha }\end{array}$} \\
\hline & & 1 & 2 & 3 & 4 & \\
\hline \multirow{4}{*}{ 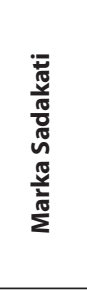 } & $\begin{array}{l}\text { S10. Arçelik'in sadık bir müşterisi olduğumu } \\
\text { düşünüyorum. }\end{array}$ & ,866 & & & & \multirow{4}{*}{, 872} \\
\hline & $\begin{array}{l}\text { S11. Diğer markaların fiyatları daha ucuz olsa bile } \\
\text { yine Arçelik markasını tercih ederim. }\end{array}$ & ,848 & & & & \\
\hline & $\begin{array}{l}\text { S12. Arçelik markasını kullanmaya devam etmeyi } \\
\text { düşünüyorum. }\end{array}$ & ,776 & & & & \\
\hline & $\begin{array}{l}\text { S13. Arçelik markasını tanıdıklarıma tavsiye } \\
\text { ederim. }\end{array}$ &, 578 & & & & \\
\hline \multirow{4}{*}{ 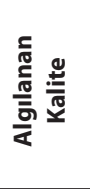 } & S16. Arçelik beklentilerimi karşılamaktadır. & & ,765 & & & \multirow{4}{*}{, 826} \\
\hline & S15. Arçelik markasının işlevselliği çok yüksektir. & & ,754 & & & \\
\hline & S17. Arçelik gelişmiş bir teknolojiye sahiptir. & & ,671 & & & \\
\hline & S14. Arçelik'in kalitesi oldukça yüksektir. & & 652 & & & \\
\hline \multirow{4}{*}{ 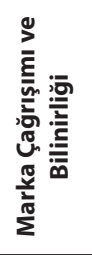 } & $\begin{array}{l}\text { S20. Arçelik'in sembol ve logosunu hemen } \\
\text { hatırlayabilirim. }\end{array}$ & & & 798 & & \multirow{4}{*}{ 789 } \\
\hline & $\begin{array}{l}\text { S21. Arçelik markası ile ilgili çağrışımları } \\
\text { hatırlamakta güçlük çekmiyorum. }\end{array}$ & & & ,772 & & \\
\hline & $\begin{array}{l}\text { S19. Arçelik'in bazı özellikleri hızlı bir şekilde } \\
\text { aklıma geliyor. }\end{array}$ & & & 661 & & \\
\hline & S18. Arçelik'in her zaman farkındayım. & & & 642 & & \\
\hline \multirow{4}{*}{ 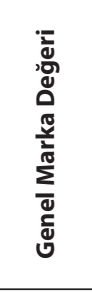 } & $\begin{array}{l}\text { S25. Arçelik markası ürünleri ihtiyaçlarıma } \\
\text { uygundur. }\end{array}$ & & & & 798 & \multirow{4}{*}{838} \\
\hline & $\begin{array}{l}\text { S26. Arçelik markasının ürün özellikleri benim için } \\
\text { uygundur. }\end{array}$ & & & & ,742 & \\
\hline & $\begin{array}{l}\text { S24. Arçelik markası ürünleri ödediğim paraya } \\
\text { değer. }\end{array}$ & & & & ,710 & \\
\hline & $\begin{array}{l}\text { S23. Arçelik kadar iyi bir marka olsa da yine de } \\
\text { Arçelik markasını kullanmayı tercih ederim }\end{array}$ & & & & 559 & \\
\hline \multicolumn{3}{|c|}{ ÖZDEĞER 7,122} & 1,773 & 1,072 & 1,052 & \\
\hline \multirow{2}{*}{\multicolumn{3}{|c|}{$\begin{array}{l}\text { AÇIKLANAN VARYANS } 19,385 \\
\text { LAM AÇIKLANAN VARYANS }\end{array}$}} & 16,793 & 16,656 & 16,032 & \\
\hline & & & & 866 & & \\
\hline \multicolumn{3}{|c|}{ KMO } & \multicolumn{2}{|c|}{,909 } & & \\
\hline \multicolumn{2}{|r|}{ BARLETT } & \multicolumn{4}{|c|}{3496,565 (sd. 120; $p=0,000$ ) } & \\
\hline \multicolumn{2}{|r|}{ Cronbach Alpha } & \multicolumn{4}{|c|}{,914 } & \\
\hline
\end{tabular}


Tablo 5: Pazarlama Amaçlı Sponsorluk ve Marka Değeri İlişkisi Korelasyon Analizi Sonuçları

\begin{tabular}{|c|c|c|c|c|c|c|c|}
\hline & & & $\begin{array}{c}\text { Pazarlama } \\
\text { Amaçlı } \\
\text { Sponsorluk }\end{array}$ & $\begin{array}{l}\text { Marka } \\
\text { Sadakati }\end{array}$ & $\begin{array}{l}\text { Algılanan } \\
\text { Kalite }\end{array}$ & $\begin{array}{c}\text { Marka } \\
\text { Bilinirliği / } \\
\text { Çağrışımı }\end{array}$ & $\begin{array}{l}\text { Genel Marka } \\
\text { Değeri }\end{array}$ \\
\hline & \multirow{2}{*}{$\begin{array}{l}\text { Pazarlama Amaçılı } \\
\text { Sponsorluk }\end{array}$} & $r$ & 1 & & & & \\
\hline & & $\mathrm{N}$ & 412 & & & & \\
\hline \multirow{8}{*}{ 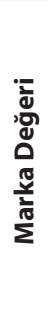 } & \multirow{2}{*}{ Marka Sadakati } & $\mathrm{r}$ &, $480^{* * *}$ & 1 & & & \\
\hline & & $\mathrm{N}$ & 412 & 412 & & & \\
\hline & \multirow{2}{*}{ Algılanan Kalite } & $\mathrm{r}$ &, $462^{* *}$ & $609^{* *}$ & 1 & & \\
\hline & & $\mathrm{N}$ & 412 & 412 & 412 & & \\
\hline & \multirow{2}{*}{$\begin{array}{l}\text { Marka Bilinirliği/ } \\
\text { Çağış̧ımı }\end{array}$} & $\mathrm{r}$ &, $500^{* *}$ &, $392^{* *}$ &, $526^{* * *}$ & 1 & \\
\hline & & $\mathrm{N}$ & 412 & 412 & 412 & 412 & \\
\hline & \multirow{2}{*}{ Genel Marka Değeri } & $r$ &, $508^{* * *}$ &, $561^{* *}$ &, $603^{* *}$ &, $579^{* * *}$ & 1 \\
\hline & & $\mathrm{N}$ & 412 & 412 & 412 & 412 & 412 \\
\hline
\end{tabular}

Tablo 6: Pazarlama Amaçlı Sponsorluk Algısı ve Marka Değeri Alt Boyutları Regresyon Katsayısı Sonuçları

\begin{tabular}{|c|c|c|c|c|c|c|c|c|}
\hline $\begin{array}{l}\text { Bağımsız } \\
\text { Değişken }\end{array}$ & $\begin{array}{c}\text { Bağımlı } \\
\text { Değişkenler }\end{array}$ & $\begin{array}{c}\begin{array}{c}\text { Standardize } \\
\text { Katsayılar }\end{array} \\
\text { Beta }\end{array}$ & $\stackrel{t}{\mathbf{t}}$ & $\stackrel{\text { p }}{\text { değeri }}$ & $\begin{array}{l}\text { Standart } \\
\text { Hata }\end{array}$ & $\mathbf{R}^{2}$ & $\begin{array}{c}\text { Düzeltilmiş } \\
\mathbf{R}^{2}\end{array}$ & $\begin{array}{c}\text { F } \\
\text { İstatistiği }\end{array}$ \\
\hline \multirow{4}{*}{ 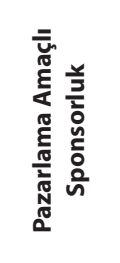 } & Marka Sadakati & ,480 & 11,067 & ,000 & ,046 & ,230 & ,228 & 122,475 \\
\hline & Algılanan Kalite & 462 & 10,537 &, 000 & ,037 & 213 & ,211 & 111,034 \\
\hline & $\begin{array}{c}\text { Marka Çağrışımı/ } \\
\text { Bilinirliği }\end{array}$ &, 500 & 11,703 &, 000 & ,038 & ,250 & ,249 & 136,954 \\
\hline & $\begin{array}{l}\text { Genel Marka } \\
\text { Değeri }\end{array}$ & ,508 & 11,954 &, 000 & 040 & 258 & 257 & 142,894 \\
\hline
\end{tabular}




\section{Şekil 1: Pazarlama İletişimi Elemanı Olarak Sponsorluk}

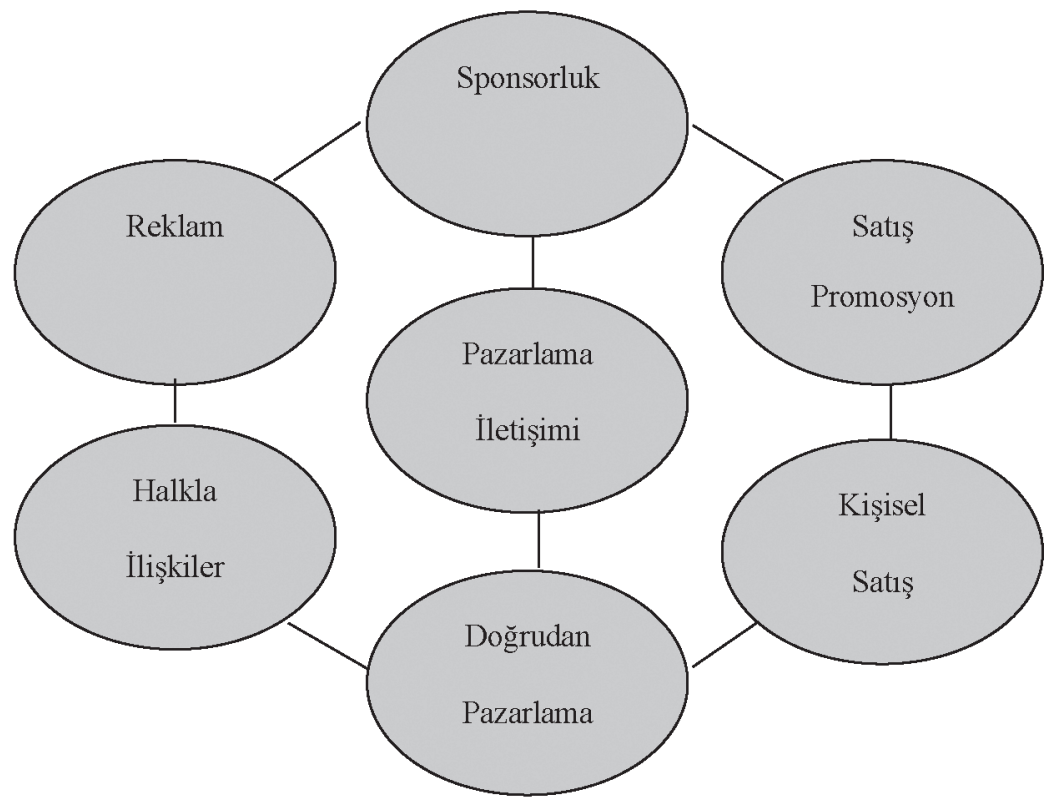

Kaynak: Masterman, 2007, p. 31.

Şekil 2: Sponsorun İletişim ve Pazarlama Amaçlarının, Etkinliğin Hedef Kitlesi ile Örtüşmesi

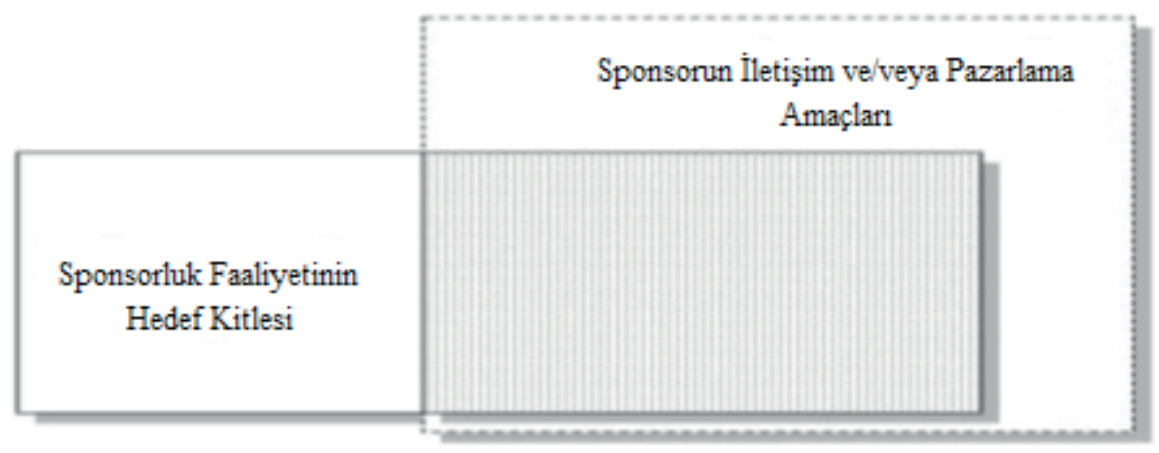

Kaynak: Ferrand et al., 2007, p. 19. 


\section{Şekil 3: Marka Değeri Yaratma Süreci}

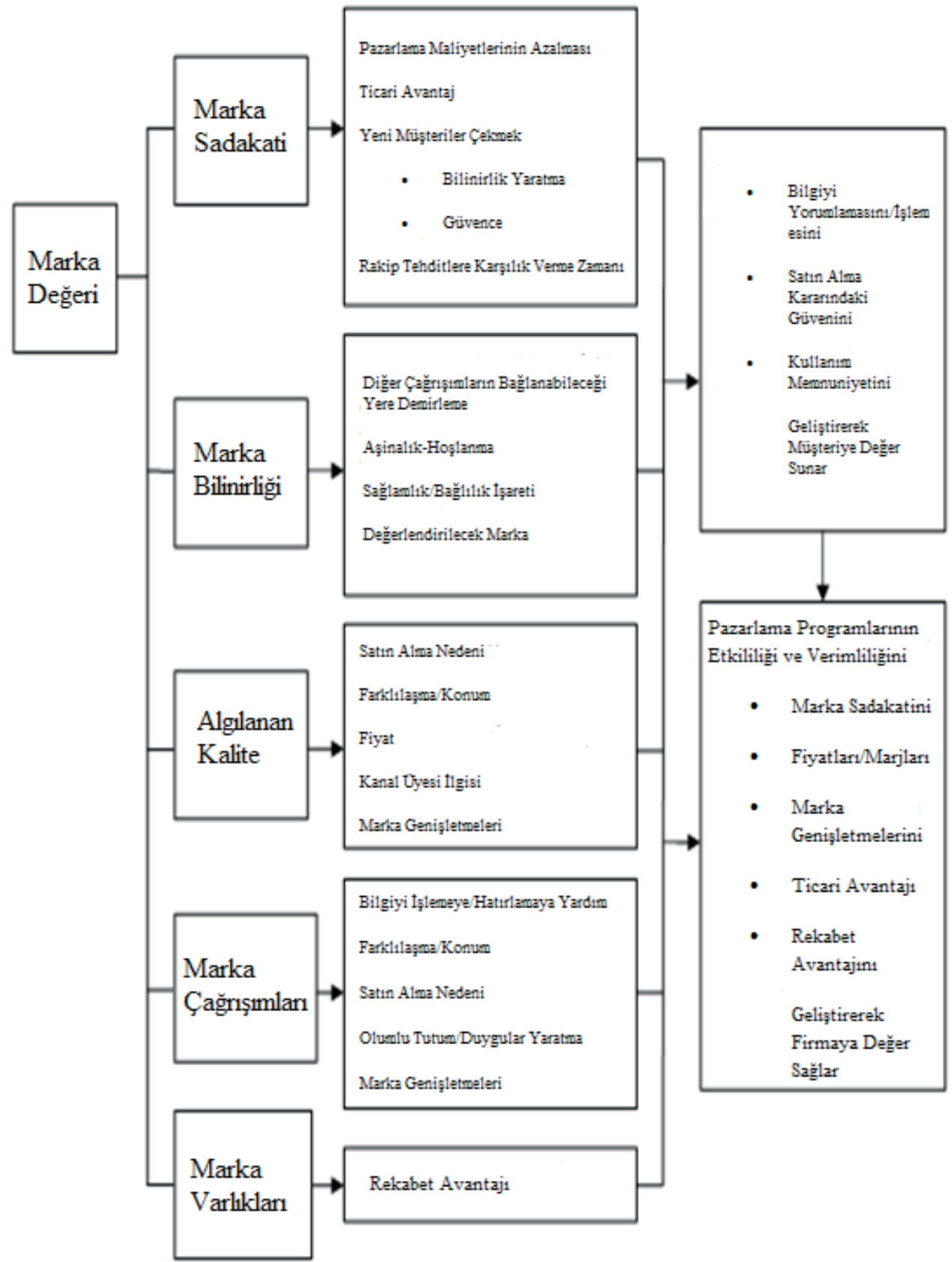

Kaynak: Aaker, 1992, p. 29. 


\section{Şekil 4: Marka Çağrışımları Neleri Amaçlayabilir?}

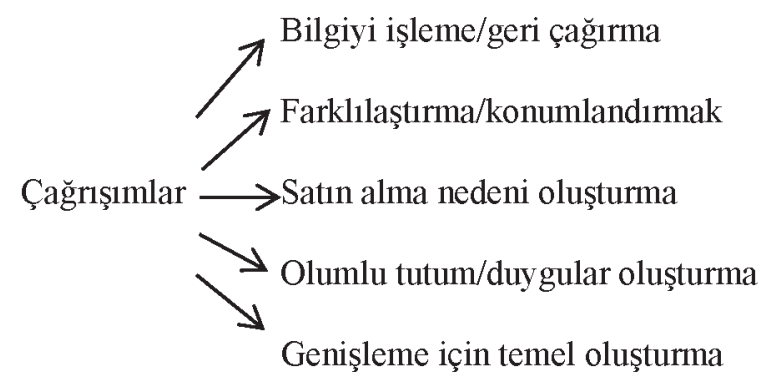

Kaynak: Aaker, 1991, p. 33.

\section{Şekil 5: Marka Sadakati Piramidi}

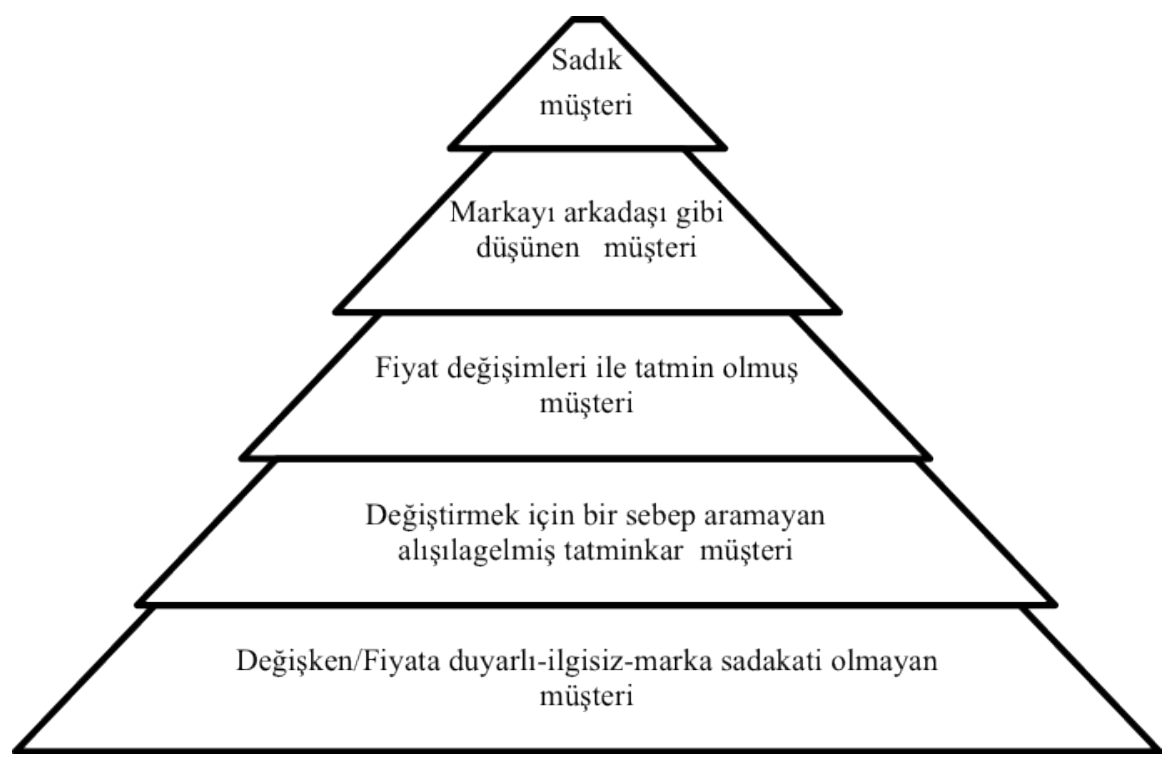


